\title{
The Art and Politics of Statues Representing "Leaders": A Case Study
}

\author{
Vladimir J. Konečni \\ Department of Psychology, University of California, San Diego, USA \\ Email: vkonecni@ucsd.edu
}

How to cite this paper: Konečni, V. J. (2019). The Art and Politics of Statues Representing "Leaders": A Case Study. Art and Design Review, 7, 41-54. https://doi.org/10.4236/adr.2019.72005

Received: February 11, 2019

Accepted: March 2, 2019

Published: March 5, 2019

Copyright $\odot 2019$ by author(s) and Scientific Research Publishing Inc. This work is licensed under the Creative Commons Attribution International License (CC BY 4.0).

http://creativecommons.org/licenses/by/4.0/

\begin{abstract}
There are two main themes in this case study of sculpture, aesthetics, and politics. First, from the viewpoint of artistic quality, the article discusses various failed features of the recent (2018) bronze statue in Belgrade of Patriarch Pavle of the Serbs (1914-2009), the prominent and widely revered head of the Serbian Orthodox Church: The work's hugely inadequate balance, pose, location, workmanship, and others. Second, the article critically describes the long-term and current political forces that constitute the social background of the design, location, and other aspects of the statue. Some of these influences are unique to Serbia in the period 1980-2018; others seem to be shared by several countries in Europe that are considered "transitional" from communism to neo-liberal capitalism.
\end{abstract}

\section{Keywords}

Statues, Statues of Famous People, Sculptures, Patriarch Pavle of Serbia, Patriarch Pavle Statue in Belgrade (Serbia), Political Influence on Statues, Sculpture and Politics, Art and Politics, Belgrade (Serbia) Statues

\section{Introduction}

Statues representing leaders, quasi-leaders or "leaders" in politics, the military, the sciences, religion, the arts, and even sports, especially when displayed not only publicly, but in important open, focal, and highly frequented areas of capital or other major cities, have long attracted a great deal of attention and controversy. The attention is guaranteed by many factors of which I offer here a non-exhaustive list (cf. De Long, 1988; Konečni, 1996; Mitrović, 2014);

1) Visibility-salience, which depends, among other variables, on:

a) the absolute size of the statue;

b) the size of the statue relative to the average human size-or else its emphasis 
on the idiosyncrasies of the represented person;

c) the size of the statue relative to the size and distance of the surrounding objects (buildings, houses of worship, fountains, other monuments, streets).

2) The historical, architectural, and metaphorical significance of the location of the statue.

3) The stylistic fit of the statue in the surrounding area-especially in terms of other structures that are used socially (shops, restaurants, bars, public, religious, and residential buildings).

4) Finally, perhaps as important as most of the other factors combined, the identity of the represented person:

a) living or non-living;

b) if not living, when deceased;

c) whether or not likely to have been often seen by, or even personally known to, many of his or her contemporaries prior to the time when the sculpture was displayed;

d) generally admired or not;

e) generally revered or not.

\section{The Case Study: Statue of the Patriarch of the Serbs Pavle (1914-2009)}

Patriarch Pavle (His Holiness Pavle or Paul; secular name Gojko Stojčević) was the $44^{\text {th }}$ supreme head of the Serbian Orthodox Church from 1990 to 2009. Orthodox Christianity is the religion of most Serbs worldwide and of most citizens of the Republic of Serbia. The Serbian Orthodox Church has been "autocephalous"-independent-since 1219, when St. Sava (Rastko, heir to the Nemanjić dynasty) received the archbishopric of "Serbian and Sea-Coastal Lands" from Patriarch Manuel I Charitopoulos of Constantinopolis (Constantinople). Autocephaly means that the Serbian Church has not ever since been subject to the authority of an external patriarch or archbishop. ${ }^{1}$

Gojko Stojčević was born in a small Serbian village in Eastern Slavonia (then Austro-Hungarian Empire, now Croatia). In 1941, he graduated from the Theological faculty in Belgrade, having also engaged in two years of medical studies. In 1948, in communist Yugoslavia, at the monastery of Blagoveštenje (Annunciation) in central Serbia, he formally became a monk and received the name of Pavle, after the apostle St. Paul. In 1957, he was ordained as Bishop of the Eparchy of Raška and Prizren, most of which is in Kosovo-Metohija (see Image 2 and Image 3). There he took care of the restoration of churches destroyed by vandals and held services throughout the Eparchy, often traveling very long distances on foot. As Bishop, he testified at the United Nations about the horrors endured by the Serbian population in Kosovo-Metohija. He was elected Patri-

\footnotetext{
${ }^{1}$ Patriarch Pavle received me for lengthy conversations, rather than interviews, with no one else present, on several occasions at the Residence of the Patriarch (Patrijaršija) in Belgrade, the capital of Serbia, in the late 1990s and early 2000s (see Image 1). In addition, I was permitted to see him at a hospital in Belgrade only a month before his passing in 2009. On that occasion, the only person present was a young monk, Metodije, who attended to His Holiness.
} 
arch on December 1, 1990, at age seventy-six, and inaugurated the next day at the Saborna crkva (Orthodox Cathedral) in Belgrade.

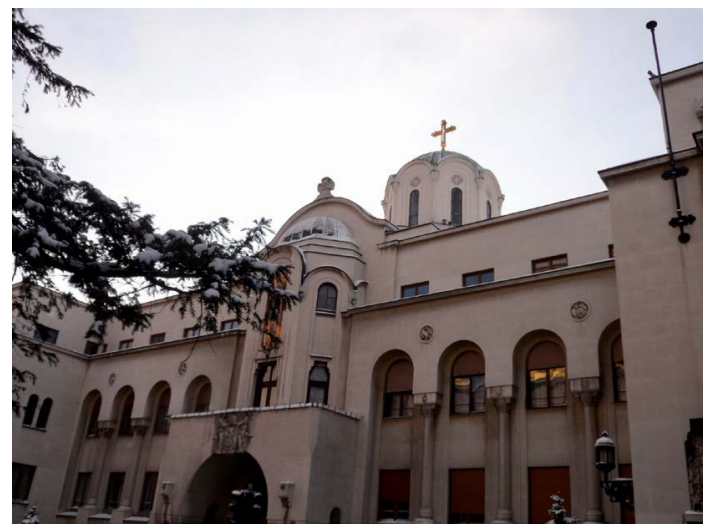

Image 1. Residence of the Patriarch of the Serbian Orthodox Church, Belgrade, Jan. 30, 2019 ㄷ V. J. Konečni.

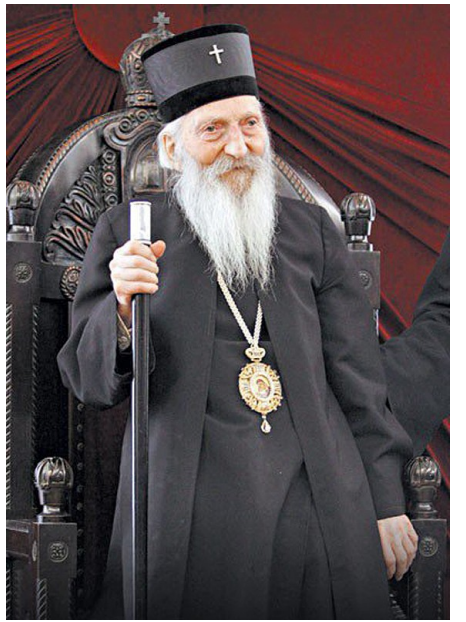

Image 2. His Holiness Patriarch Pavle.

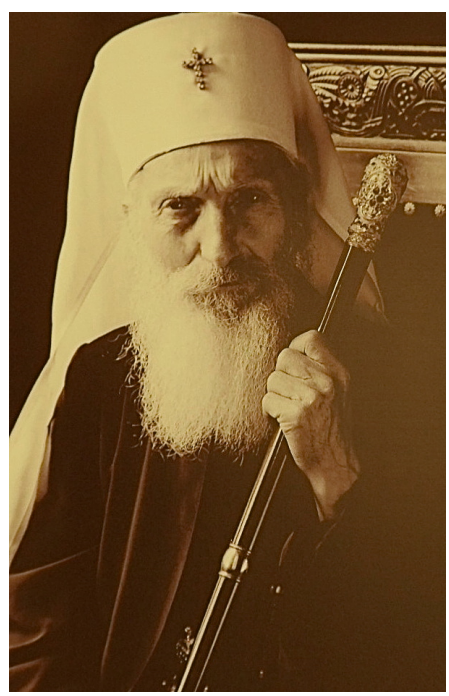

Image 3. His Holiness Patriarch Pavle. 


\section{Patriarch Pavle the Humanist}

Pavle was Patriarch of the Serbs at a tumultuous time in Yugoslavia and Serbia: the break-up of federal Yugoslavia and the three-sided civil wars of the 1990s, as well as the crushing bombardment of Serbia for seventy-eight days and nights in 1999 (March 24-June 10), with a large number of civilian casualties, by the nineteen countries of the North Atlantic Treaty Organization (NATO), led by the United States. Pavle's public and private behavior throughout the last nineteen years of his life must be-by any a half-objective person-described as humanist in the best sense. He abhorred violence on any side's part, and he loved his own people and the various enemies equally. He propounded the ancient Christian spirit and by all accounts lived a truly Christian life.

In the almost twenty years that he lived in Belgrade, he became a living legend in the eyes of a large number of people. He walked everywhere without any security personnel, he talked to the poorest and the richest, and he ran with his stick after buses and streetcars (see Image 4 and Image 5). He was the most

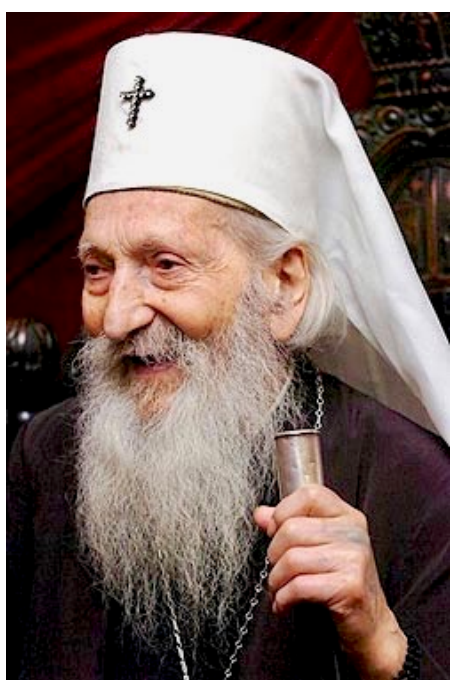

Image 4. His Holiness Patriarch Pavle.

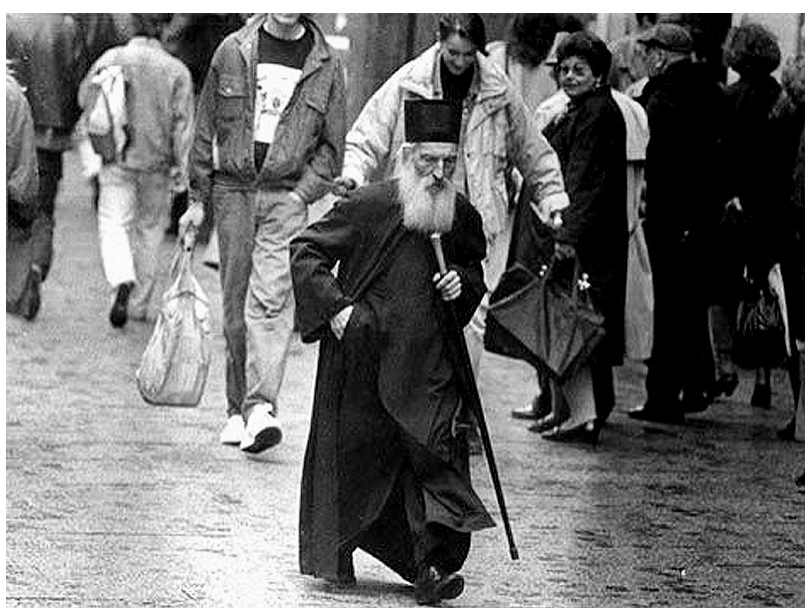

Image 5. His Holiness Patriarch Pavle. 
unpretentious and kind man that the ordinary people have known. Long before his passing, the descriptor for him that one heard-and not just from the poor and the farmers at the markets-was "saintly." Pavle, as he was called by all, was the epitome of goodness to the huge majority of Serbs. He was buried in 2009 at Rakovica, a small $16^{\text {th }}$ century humble monastery, dedicated to the archangels Michael and Gabriel, on the outskirts of Belgrade, by his own wish, and in line with his lifelong modesty.

The subsequent critique of the statue and the comments of the passersby cannot be properly understood without this preamble.

\section{The Social and Political Background of the Statue}

Years passed and more tumult at Pavle's beloved Serbian southern province of Kosovo-Metohija ensued. It was recognized by many countries as a separate, sovereign state, even though it was a case of unilateral, self-proclaimed, secession by Albanians living in a province that is filled with Serbian mediaeval churches, monasteries, and other ancient monuments (cf. Strugar, 2018). Furthermore, it has not been recognized by about half of the countries in the world, including P. R. China, the Russian Federation, and even five countries of the European Union, among others. In Serbia, the new Patriarch, His Holiness Irinej (whom I also have the honor of knowing personally), had his hands full of objective problems; and perhaps he did not have a genuine stake in contributing to what could be perceived as excessive love of Pavle.

But Pavle was certainly not forgotten by the ordinary people-even though unlike Russia, and especially unlike certain Roman Catholic countries, such as France, Spain, Mexico, and Croatia, Serbia is not a place where "magical" (and financially lucrative to many) grottos exist, with the expectation of "visions" and "miracle cures." Nevertheless, there certainly had not been any loud clamoring by the poor or the middle class for a public recognition in the form of a statue for Pavle at a prominent public location.

A word is in order about what constitutes the middle class in Serbia now. The old aristocratic, pro-monarchist, and traditional middle classes were for the most part physically destroyed by the regime that was-with extreme violenceinstalled in October of 1944 by Josip Broz (see U. Krstić, 1994). This person, nicknamed "Tito", was a man of uncertain national origin, deeply within the breast of the ultra-secretive pre-World War II international communist organization, the Komintern (Simić, 2016: Vol. 1). As a consequence of this regime that lasted four and a half decades, most of them under the Broz personality cult, the present so-called middle class consists mostly of ex-communist party members and their heirs (Dj. Krstić, 2017; Ocić, 2012; Simić, 2018: Vol. 2). After the fall of communism in Europe, many of them overnight embraced the so-called "western values," amply financed by the "open society" ideologues (some of them currency speculators), such as George Soros (born Schwartz György). Many of the best and brightest have been leaving Serbia for decades and the 
process presently continues. The country has been left in charge of mediocrities, engaged in opportunistic party strife. The massively impoverished workers and farmers have had no one to fight for them, despite the existence of parties with names like "socialist" (ex-communist) and "progressive."

In short, until almost ten years after Pavle's passing, there had been no public outcry for a statue of "our Pavle." The poor have had a hard time making a living and the strivers have been busy joining the ranks of the currently ruling "progressive" party. As in many other post-communist countries in Europe, there have been corrupt "tycoons," many of them half-literate people with murky backgrounds.

Most of the individuals mentioned in the previous paragraphs-from ex-communists who have embraced "neo-liberal" western values, to the strivers - are secular or anti-religious. Again, it is with this information in mind that the following critique of the statue must be contemplated.

\section{The Statue-Preliminaries}

Nevertheless, for unfathomable reasons, there came in early 2018 the announcement that a statue of Patriarch Pavle would be revealed in late fall in Belgrade's renowned, central Tašmajdan Park. There was no international competition, something one would have expected to be done for such a personage and prestigious location. Information about the sculptor was disclosed in small doses, in secondary newspapers. The sculptor's name, Zoran Maleš (born in 1962) of Belgrade, meant little to most art experts and to the public. He was someone of modest opus, especially for his age (56). Later, Maleš announced to a semi-tabloid that he would work on a clay model of the statue in July of 2018 at the art colony "Tera" in Kikinda (north Serbia), and that it would be cast in bronze at the foundry "Janković" in Belgrade. It was allegedly financed by 50,000 euro (US\$57,000) from the sometimes mysterious "Atlas Group." Significantly, to my knowledge, no curatorial or public opinion was ever sought or obtained, nor was a maquette ever displayed.

\section{The Statue Revealed}

The main Belgrade daily newspaper Politika-continuously published since 1904, of high quality in many ways, but often swaying to political winds-announced in its back pages that the statue would be revealed on the $15^{\text {th }}$ of November (2018), but did not then or later disclose the hour. Quite likely the reason-as those few who managed to be present could see (around fifty people, including myself) - was that the President of the Republic would not be, and was not, present, nor was the Minister for Culture. Most telling or disappointing, depending on the (unknown) reason, was the absence of the current Patriarch of the Serbs, His Holiness Irinej. One should perhaps note that it was a sunny and pleasant day.

The bronze statue (about $180 \mathrm{~cm}$ high) shows Patriarch Pavle seated "on air," 
with his head bowed down. It is located at the extreme northwestern edge of Tašmajdan Park. Behind it is a streetcar terminal and in front of it, across a walkway, the large terrace of a restaurant. The church of Sveti Marko looms nearby.

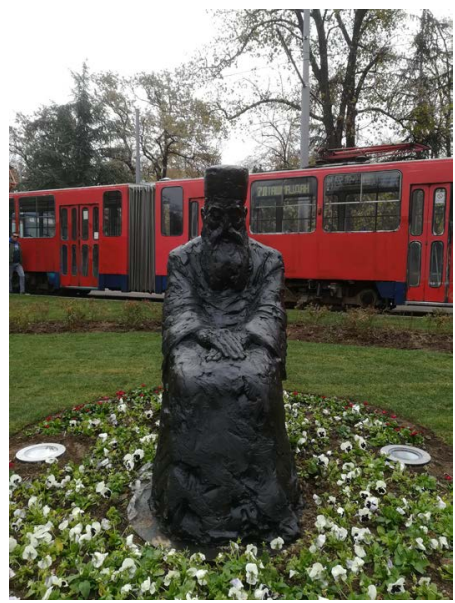

Image 6. Statue of Patriarch Pavle, Nov. 16, 2018 (C) V. J. Konečni.

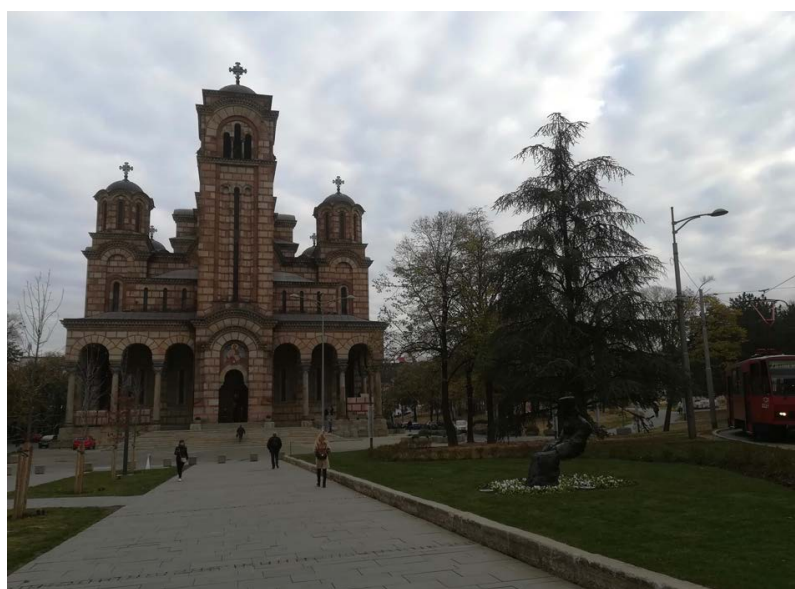

Image 7. Church of Sv. Marko with statue of Patriarch Pavle, Nov. 16, 2018 @ V. J. Konečni.

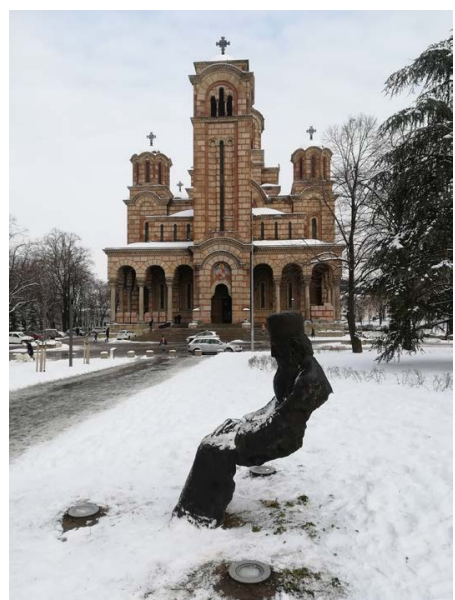

Image 8. Church of Sveti Marko with statue, Jan. 7, 2019, Serbian Orthodox Christmas @ V. J. Konečni. 


\section{Essential Features of the Statue and Its Location}

In all the arts, from theater to sculpture, the mixing of genres, of the conceptual approaches to the artwork, is a risky undertaking. Even in the postmodern contempt for tradition, the cleverly designed artwork can be successful-perhaps funny or titillating-because it asks the spectator to wonder about the underlying point, purpose, or intention, one that may be fuzzy or even nonexistent. Unfortunately, when there is a confused mix of ideas and a poor embodiment of some intended metaphor, the work can end up being grotesque. Precisely that is the case with the sculpture of Patriarch Pavle that was revealed in Belgrade (Konečni, 2018).

\subsection{The Statue}

En face, the details could be described as realistic: The face, hands, and fingers (see Image 6). The lower part of the body is fixed to the ground, but its entire upper part, at an angle of at least $45^{\circ}$, is bent backward, without any support. There is a massive absence of gravitational balance inherent in the sculpture (see Images 7-9). While I lingered in the vicinity of the statue, watching and listening unobtrusively, I wrote down snatches of conversation. Some ordinary believers walking to the church murmured to each other: "To our Saint, our Pavle, they did not even give a chair, let alone a throne; he will, poor sweet man, fallmay God forgive me (the middle-aged woman crossed herself)—on his behind!" Whereas the secular well-dressed couples whispered to each other: "As soon as there is a little ground movement, this one will break up at the hip, ha, ha!" Clearly both of these predictions amounted to an ugly joke, something denigrating, in which the sculptor and the spectators collaborated.

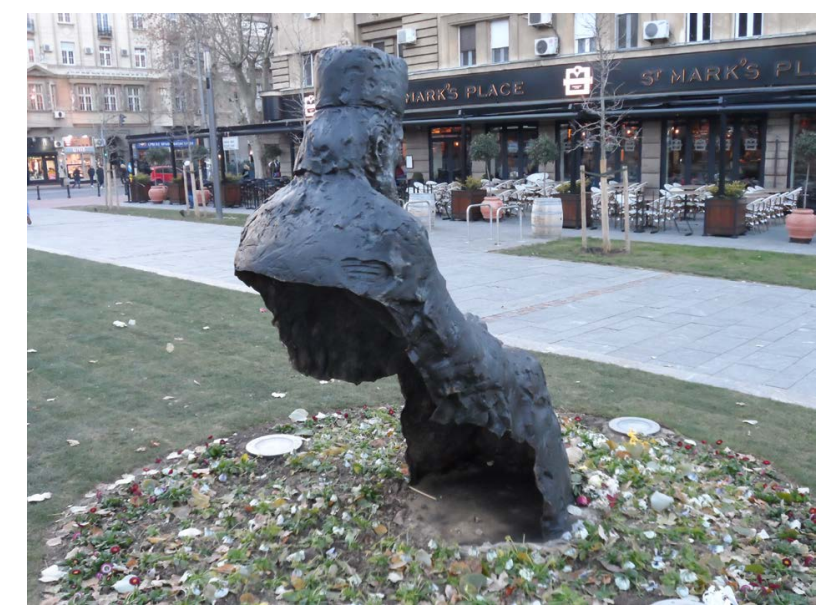

Image 9. Statue of Patriarch Pavle, Nov. 30, 2018 @ V. J. Konečni.

What could have led the sculptor Maleš to seek this absence of balance? One possibility is that the spectator walking toward the sculpture from the profile, either from Sveti Marko, or from the nearby Boulevard of King Alexander, would say inwardly: "Is Pavle hovering? What for? I should look closer." A plus 
for the artist. Art always sought to accomplish an invitation and the consequent approach.

But was the sculptor not aware that people come close and look at a sculpture from various angles? Spending hours talking to passersby and believers on their way to and from the church, I encountered an almost univocal distaste for the statue. ${ }^{2}$ Close proximity brought dislike rather than liking, love, admiration or awe (Konečni, 2005). The often mentioned "clumsy" absence of balance seemed to play a large part in the highly negative judgments. The citizens of my native city unanimously said something like this: "They humiliated our beloved Pavle into this ugly posture, without spirit... typical of this..." The statement "typical of this..." was often not left unfinished, but instead referred to the country's government in general, and the daily and long-term administration of Belgrade specifically. An unforgivable minus for the artist (Konečni, 2018).

\subsection{The Pose}

The pose shows a decrepit man who is unhappy, beaten, without will or hope for himself or his people. My reading of the sculpture is that the Patriarch is looking down at his knees (if his eyes are open), feeling lonely and abandoned. Why?

As was mentioned earlier, many citizens of Belgrade (myself included) see Pavle in their inner eye running for the bus with his cane-kind, polite, full of life...beautiful! Four men who had known Pavle in the town of Prizren, in Kosovo-Metohija, when he was Bishop of Raška and Prizren, talked to me in front of the statue: "We knew Pavle as a man full of energy, lucid, kind, fearless, and often smiling (see Image 10). And this... this looks like a dotard who doesn't care for anyone. An injustice and a shame!"

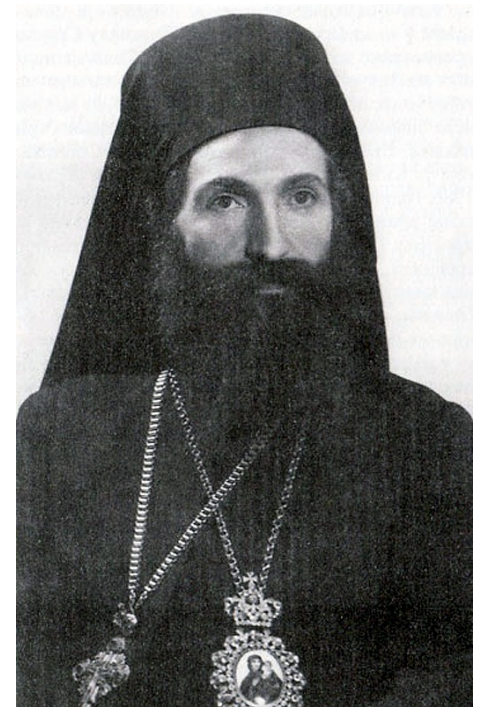

Image 10. Patriarch Pavle when Bishop of Raška and Prizren, 1959.

${ }^{2}$ The author of the article is a qualified social psychologist and methodologist who does not suggest or impose answers on respondents. 
There is an important art-historical and even social and political question to ask: Should a young or middle-aged sculptor, such as Maleš (born in 1962), whose work is supposedly "forever," realistically represent a historical personage in a very late stage of life simply because they were contemporaries for a number of decades? My answer is sharply negative. ${ }^{3}$ The reason for such a critical judgment is to defend "the truth" to which realism in art allegedly aspires. Realism should not be a cloak under which to hide condescension toward the represented personage. Do it openly, through good art, realistic or not, but not by means of sneaking in very old age in your mediocre art (Konečni, 2018; Mitrović, 2012).

It might be argued that Pavle's pose is supposed to reflect the defeat and disillusionment he experienced as a function of the war in Kosovo-Metohija in the 1990s and the NATO bombs falling all over Serbia in 1999 (cf. Malvern, 2017). But there is no supplementary evidence for such a view.

\subsection{The Location}

The location of the statue is abysmal. This may be the sculptor's fault only to the extent that he accepted the two square meters of ground allotted to the statue by the managers of the city of Belgrade-in their superficiality and incompetence regarding art.

First, instead of the massive, monumental church of Sveti Marko spiritually complementing the statue, it dwarfs it and makes it look trivial-an almost hilarious appendix (see Image 7). The respective proportions of the church and the statue are wrong, which means that the location is wrong; the statue is a pathetic miniature.

Second, behind the statue, as was mentioned, is a streetcar terminal. This means that tram-cars arrive there and stay a long time, which means, in turn, that the sculpture, when observed from the front, is most of the time framed not by the pleasant greenery of the park (as rendered perhaps in some salesmanship to sponsors), but by a massive streetcar (see Image 6). This is an elementary point in public sculpture and design, of which the sculptor had to be aware and reject, for this reason alone, the placement allotted to the statue (cf. Giedion, 1941/2009).

Third, there is the proximity of some fifteen meters to the large terrace of the restaurant across the walkway (Image 9). The statue of a very kind and good person, relatively recently deceased, and saintly to many, is bizarrely wrong in the proximity of having a cappuccino while chatting on the phone. It is a somewhat obscene sort of performance. Let's face it: This location and Patriarch Pavle are not related to the Piazza della Signoria in Florence.

One angry passerby said to me: "They placed this ludicrous sculpture of Pavle so that he is forced to stare at the English name of City Manager's café!" This

${ }^{3}$ The sculpting mannerism of representing famous people realistically as will-less ancients is not to be found only in Belgrade. As one other example, one can mention the statue of Borislav-Bora Kostić (1887-1963), a renowned intellectual and the first Serbian chess grandmaster, that is located at the Flower Promenade in the town of Vršac (northeast Serbia): A fine realistic sculpture of a man who looks like a vagrant, a clochard out of Maigret. 
critic misinterpreted the pose, and was mistaken about the ownership of the café, but was in any case referring to the energetic, much disputed, City Manager of Belgrade, a Vice-President of the ruling SNS party, who has been advocating, on a daily basis, the "new face of Belgrade." It is exemplified by the detested skyscrapers next to the banks of the two beautiful Belgrade rivers, Sava and Danube, and in many other intrusive ways. Objectively, that "face" is by no means all pockmarked or pimply, but with the improvements arrive too many signs in English and in the Latin alphabet, instead of the Serbian, supposedly official, $\mathrm{Cy}$ rillic. In any case, the passerby's comment added to the impression that the location of the statue is poor.

Tašmajdan Park is large, beautiful, and with thousands of years long and varied history. It contains a variety of dedicated areas and monuments. Certainly, a more appropriate place for Patriarch Pavle could have been found-perhaps behind Sveti Marko, near the tiny Russian church of Holy Trinity, with its tender blue domes, which would correspond to Pavle's modesty and soulful peace.

If the statue were placed on that location, and Pavle, facing the church, was magically able to look to his right, he would see and feel again the destructive horror on the building of Radio-Television of Serbia caused by the NATO bombardment of 1999. That bombardment was called by the aggressor, with extreme cynicism-given the enormous civilian casualties and the nonexistent declaration of war-the mission "Merciful Angel".

\section{Conclusion}

To absolutely no one of the many dozens of people who spontaneously addressed me while I stood vigil by the statue during many times of day over close to two months was this statue dear, nor did it, in any way, represent their intimate relationship to Pavle, their feeling of love and the sublime (Konečni, 2011). One woman from the town of Paraćin in central Serbia said to me: "This monstrosity should be melted into... something." I do not agree with the destruction of art under almost any circumstances, but there is the "almost" caveat.

\section{The Ivo Andrić Addendum}

Many of the points in the article, which were stated or implied between the lines about the detrimental long-term and current political influences on the various features of the statue of Patriarch Pavle, can be indirectly validated by the counter-example of another statue in Belgrade (see Image 11 and Image 12). "Indirectly validated," because the statue in question, of the writer Ivo Andric (of uncertain, or any, religious affiliation in adulthood), is as nonpolitical as any public sculpture can be. Andrić (1892-1975) received the Nobel Prize in literature in 1961 and was celebrated by all the political systems that have been dominant

${ }^{4}$ The world is sometimes absurdly small. The Radio-Television of Serbia building is located about $350 \mathrm{~m}$. from the one in which the author's apartment is located. The attack occurred at 2:06 at night on April 23, 1999. Sixteen innocent workers and technicians were killed and another sixteen wounded. 
in Serbia (including the communist one of J. Broz). In 1992, the centenary of Andrić's birth, a realistic bronze statue $(225 \mathrm{~cm}$ high) — created by the Serbian sculptor Milanko Mandić (1951-2010) and signed by him in 1991-was placed on the upper end of Andrićev venac (Andrićs Wreath). This is a beautiful 100-meter articulated slope with broad marble stairs and a stream in a marble bed that adjoins the side of Novi dvor (the New Royal Palace of the Karadjodjević dynasty of Serbia and post-First World War Yugoslavia). The slope was named after Andrić because for many decades he had lived on the first floor of a building that is located about forty meters, as the crow flies, from where his statue was placed and is now. His windows looked on a pretty, serene park that was once the royal garden with two spectacular ginkgo trees. The location is in the heart of aristocratic Belgrade and there are no restaurants or bars within three hundred meters.

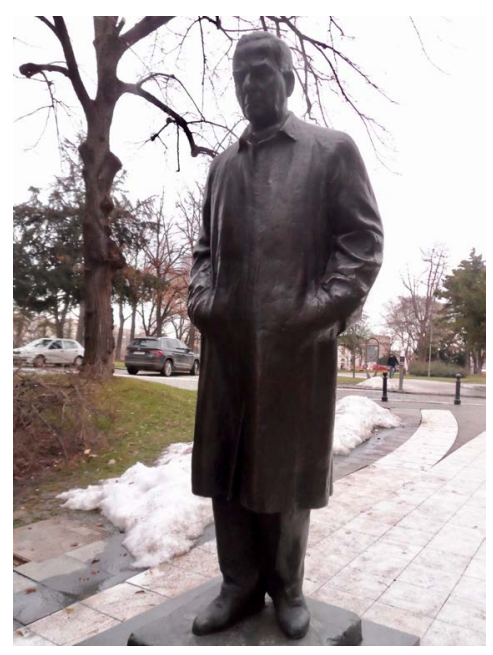

Image 11. Ivo Andrić (sculptor M. Mandić 1991), Feb. 2, 2019 @ V. J. Konečni.

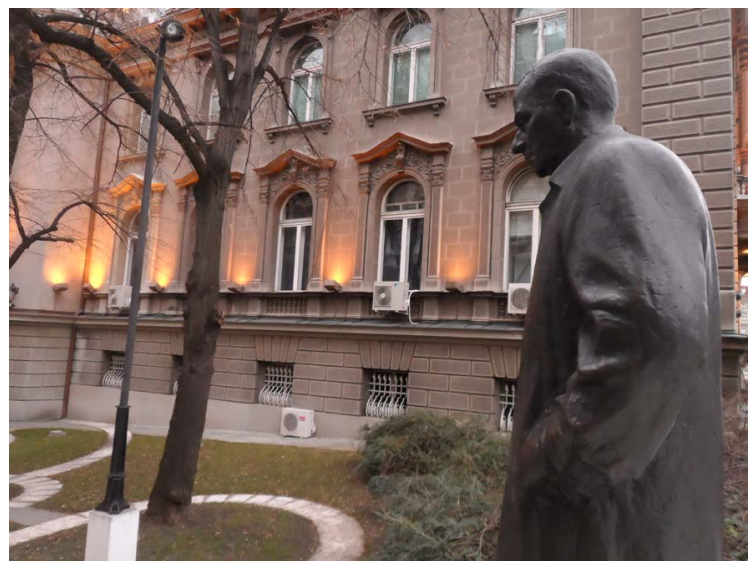

Image 12. Ivo Andrić (sculptor M. Mandić 1991), Feb. 2, 2019 (C) V. J. Konečni.

To intellectuals, Andrić is a famous writer. To ordinary people, he is someone they heard of. If they went to school, they read the approved short parts of his most famous book Na Drini ćuprija ("The Bridge on the Drina"). Many intel- 
lectuals admire Andrić, but do not revere him. The ordinary folk do not love him, let alone call him "our Ivo."

The contrast of Andrić's statue to Patriarch Pavle's is striking and there is little doubt that it can be attributed to raw politics, its presence or absence, without subtle complications. The genuine love of the people for someone they consider saintly and kind can be dangerous for imposed regimes, especially when reverence is accompanied by religious faith, and when that faith is dominant in a country-while being simultaneously both anti-communist and anti-“western values." In contrast, an aloof, seemingly apolitical intellectual can survive any regime; his spacious apartment (turned into a museum), his marble slope, and his skillfully created, realistic statue can be shown off to visitors as proof of a regime's respect for the arts.

Under such circumstances, the city of Belgrade could, and did, have a genuinely anonymous design contest, one that was won fairly by the sculptor Mandić. There was no mysterious sponsor. He created a true-to-life, dignified statue, without aggrandizing himself; and he did not place the person portrayed, a great writer, on his deathbed-decrepit and disillusioned-which he could have done given Andrić's passing at the age of eighty-two.

\section{Conflicts of Interest}

The authors declare no conflicts of interest regarding the publication of this paper.

\section{References}

De Long, D. G. (1988). Bruce Goff: Toward Absolute Architecture. Cambridge, MA: The Architectural History Foundation \& MIT Press.

Giedion, S. (2009). Space, Time and Architecture: The Growth of a New Tradition (5th. Rev. \& Enl. ed.). Cambridge, MA: Harvard University Press. (Original work published 1941)

Konečni, V. J. (1996). Politika i social'naya ekologiya arkhitektur'i [Politics and the Social Ecology of Architecture]. Kul'turologicheskie Zapiski, 2, 175-189.

Konečni, V. J. (2005). The Aesthetic Trinity: Awe, Being Moved, Thrills. Bulletin of Psychology and the Arts, 5, 27-44.

Konečni, V. J. (2011). Aesthetic Trinity Theory and the Sublime. Philosophy Today, 55, 64-73. https://doi.org/10.5840/philtoday201155162

Konečni, V. J. (2018, November 28). Poniženje voljenog patrijarha Pavla [The Humiliation of the Beloved Patriarch Pavle]. Danas, p. 9.

Krstić, Dj. (2017). Balkan kao sudbina-vremena predeli ljudi [The Balkans as FateTimes Landscapes People]. Belgrade: Službeni Glasnik.

Krstić, U. (1994). Najlepši poziv na svetu—zabeleške jednog izdavača (B. Živojinović, Ed.) [The Most Beautiful Calling in the World-Notes of a Publisher]. Belgrade: Biblioteka Vajat.

Malvern, S. (2017). Contemporary Wars; Contemporary Art. In J. Bourke (Ed.), War and Art: A Visual History of Modern Conflict (pp. 166-194). London: Reaktion Books.

Mitrović, M. (2012). Arhitektura Beograda 1950-2012 [Architecture of Belgrade 1950-2012]. Belgrade: Službeni Glasnik. 
Mitrović, M. (2014). Arhitektura u svetu i kod nas (T. Anić, Ed.) [Architecture Around the World and in Yugoslavia/Serbia]. Belgrade: DPC Publishers.

Ocić, Dj. (2012). Pod sumnjom-dani u Beogradu [Under Suspicion-Days in Belgrade]. Belgrade: Službeni Glasnik.

Simić, P. (2016). Tito i Srbi (knjiga 1, 1914-1944) [Tito and the Serbs (Vol. 1, 1914-1944)]. Belgrade: Laguna.

Simić, P. (2018). Tito i Srbi (knjiga 2, 1945-1972) [Tito and the Serbs (Vol. 2, 1945-1972)]. Belgrade: Laguna.

Strugar, V. (2018). Jugoslovenski 1. decembar 1918.-Stogodišnjica za spomen [The Yugoslav First of December, 1918. - A Centenary Commemoration]. Belgrade: Zavod za udžbenike. 